\title{
Nitrogen Metabolism in Rhodospirillum rubrum: Characterization of Glutamate Synthase
}

\author{
By M. MELANIE YELTON AND DUANE C. YOCH* \\ Department of Biology, University of South Carolina, Columbia, South Carolina 29208, \\ U.S.A.
}

(Received 26 August 1980; revised 8 October 1980)

\begin{abstract}
Glutamate synthase, an enzyme involved in glutamate biosynthesis in nitrogen-deficient environments, has been purified 200 -fold from the photosynthetic bacterium Rhodospirillum rubrum. The in vivo association of this NADPH-linked glutamate synthase with the photosynthetic membranes was suggested by its co-sedimentation with the chromatophore membranes and its ability to couple glutamate formation to light-generated reducing power. Although it was not homogeneous, the enzyme co-chromatographed with iron after three successive column chromatography steps and had the spectrum of a flavoprotein which suggests it may be an iron-sulphur flavoprotein similar to the enzyme from other prokaryotes. The $K_{\mathrm{m}}$ values of glutamate synthase for NADPH, glutamine and 2-oxoglutarate were $15 \mu \mathrm{M}$, $130 \mu \mathrm{M}$ and $35 \mu \mathrm{M}$, respectively. The molecular weight of glutamate synthase was salt-dependent in that the enzyme isolated in $0.4 \mathrm{M}-\mathrm{NaCl}$ showed a molecular weight of 840000 , whereas in the absence of salt the molecular weight was about 260000 . This phenomenon may be common to other glutamate synthases, since the molecular weight of this enzyme from Klebsiella pneumoniae was also influenced in a similar manner by $\mathrm{NaCl}$.
\end{abstract}

\section{INTRODUCTION}

There is now considerable evidence to suggest that the photosynthetic bacteria utilize the glutamine synthetase (EC 6.3.1.2)/glutamate synthase (EC 1.4.1.13) pathway for the assimilation of $\mathrm{NH}_{4}^{+}$and biosynthesis of glutamate when growing with $\mathrm{N}_{2}$ gas or low concentrations of $\mathrm{NH}_{4}^{+}$as the nitrogen source (Johansson \& Gest, 1976; Weare \& Shanmugam, 1976; Brown \& Herbert, 1977 $a, b$ ). Glutamine synthetase catalyses the ATP-dependent synthesis of glutamine from glutamate plus $\mathrm{NH}_{4}^{+}$, whereas glutamate synthase catalyses the $\mathrm{NAD}(\mathrm{P}) \mathrm{H}$-dependent amination of 2-oxoglutarate with glutamine as amino donor, yielding two molecules of glutamate. In addition to the assimilation of $\mathrm{NH}_{4}^{+}$to form glutamate, glutamine synthetase (Wall \& Gest, 1979) and glutamate synthase (Weare, 1978) have also been implicated in the regulation of nitrogenase synthesis in the Rhodospirillaceae. These enzymes from photosynthetic bacteria have not, however, been well characterized. Glutamine synthetase has only been characterized from Rhodopseudomonas capsulata, and, like the enzyme from enteric bacteria, it was shown to be regulated by an adenylylation/deadenylylation system (Johansson \& Gest, 1977) and repressed by $\mathrm{NH}_{4}{ }^{+}$ (Johansson \& Gest, 1976; Brown \& Herbert, 1977b; Herbert et al., 1978). Glutamate synthase has not been characterized in any of the photosynthetic bacteria.

Glutamate synthase has been purified from Escherichia coli (Miller \& Stadtman, 1972), Klebsiella aerogenes (Trotta et al., 1974), Thiobacillus thioparus (Adachi \& Susuki, 1977) and Bacillus megaterium (Hemmilä \& Mäntsälä, 1978) and was found to be an iron-sulphur flavoprotein. Virtually nothing, however, is known about glutamate synthase in the 
photosynthetic bacteria except that it is NADPH-dependent in the purple nonsulphur bacteria (Nagatani et al., 1971; Johansson \& Gest, 1976; Brown \& Herbert, 1977b; Herbert et al., 1978) and NADH-linked in the purple sulphur bacteria (Nagatani et al., 1971; Brown \& Herbert, $1977 a$ ). The characteristics of this enzyme are of interest because of its possible involvement in the regulation of nitrogenase activity by modulating glutamine levels in the purple nonsulphur bacteria (Neilson \& Nordlund, 1975; Carithers et al., 1979; Jones \& Monty, 1979).

\section{METHODS}

Growth conditions. Rhodospirillum rubrum S-1 (kindly provided by D. I. Arnon) was grown photosynthetically as described previously (Yoch, 1979) on the medium of Ormerod et al. (1961) which was modified by omitting the glutamate. Bacteria used for purification of glutamate synthase were grown on excess $(10 \mathrm{mM})\left(\mathrm{NH}_{4}\right)_{2} \mathrm{SO}_{4}$ to obtain maximum cell yield and repress synthesis of nitrogenase which was a major source of contaminating iron protein.

Klebsiella pneumoniae strain M5A1 was cultured on media described previously (Yoch \& Pengra, 1966).

Partial purification of enzyme. Cultures used for the purification of glutamate synthase were harvested by continuous centrifugation with a CEPA model LE centrifuge (New Brunswick Scientific) cooled with circulating water. Bacteria $(60 \mathrm{~g}$ wet wt) were resuspended in 2 vol. of cold $330 \mathrm{~mm}$-Tricine buffer $(\mathrm{pH} 8.5)$ and broken by ultrasonic oscillation for three $30 \mathrm{~s}$ periods using a Bronwill Biosonic IV cell disruptor (VWR Scientific, Bridgeport, N.J., U.S.A.) at $65 \mathrm{~W}$ output. The cell extract was centrifuged at $30000 \mathrm{~g}$ for $10 \mathrm{~min}$ to remove cell debris and the pellet was discarded. The supernatant was centrifuged at $240000 \mathrm{~g}$ for $90 \mathrm{~min}$ to separate the chromatophore membranes (which pelleted) from the soluble proteins. The pellet (which contained variable amounts of glutamate synthase bound to the membrane) was again discarded and the supernatant was brought to $35 \%$ saturation with a saturated solution of $\left(\mathrm{NH}_{4}\right)_{2} \mathrm{SO}_{4}$. The mixture was stirred for $15 \mathrm{~min}$ in an ice bath and centrifuged at $30000 \mathrm{~g}$ for $10 \mathrm{~min}$. The pellet was discarded and the supernatant was brought to a $45 \%$ saturation with $\left(\mathrm{NH}_{4}\right)_{2} \mathrm{SO}_{4}$. Again the solution was stirred for $15 \mathrm{~min}$ and centrifuged. The resulting pellet contained about $75 \%$ of the soluble glutamate synthase activity and was dissolved in a minimum volume of buffer A [50 mM-Tricine buffer ( $\mathrm{pH} 8 \cdot 0$ ) containing $2 \mathrm{~mm}$-2-oxoglutarate and $10 \mathrm{~mm}$-2-mercaptoethanoll.

For enzyme that was to be characterized enzymically, $1 \mathrm{ml}$ portions of the 35 to $45 \%\left(\mathrm{NH}_{4}\right)_{2} \mathrm{SO}_{4}$ precipitate were chromatographed on a Sephacryl S300 column $(1 \times 60 \mathrm{~cm})$ equilibrated with buffer A containing $0.4 \mathrm{M}-\mathrm{NaCl}$. Fractions from this column containing maximal activity were used to determine the $\mathrm{pH}$ and temperature optima and the substrate saturation kinetics.

To determine the iron content and spectral properties of glutamate synthase, it was further purified by chromatography on two successive Whatman DE-52 cellulose columns $(2.5 \times 7 \mathrm{~cm}$ and $1 \times 5 \mathrm{~cm})$, both being eluted with a $30 \mathrm{ml}$ gradient of buffer A containing 0.1 to $0.4 \mathrm{M}-\mathrm{NaCl}$. In each case the fractions containing maximum activity were pooled and applied to the succeeding column. The resulting glutamate synthase preparation was purified about 200 -fold; however, the yield was less than $5 \%$ of the starting material.

Enzyme assays. Glutamate synthase activity was assayed by following the oxidation of NADPH spectrophotometrically at $340 \mathrm{~nm}$ at 20 to $23^{\circ} \mathrm{C}$. Reaction mixtures $(2 \mathrm{ml})$ contained: $50 \mathrm{~mm}$-Tricine buffer $(\mathrm{pH}$ $8.0), 0.5 \mathrm{~mm}$-2-oxoglutarate, $0.15 \mathrm{~mm}-\mathrm{NADPH}$, and enzyme. The glutamate synthase reaction was monitored for 2 min to obtain values for background oxidation of NADPH and then $5 \mathrm{~mm}$-glutamine was added to initiate the reaction. The background rate (which after the first column step was very low) was always subtracted to obtain the rate of glutamine-dependent NADPH oxidation. One unit of glutamate synthase is defined as the amount of enzyme needed to oxidize $1 \mathrm{nmol}$ NADPH $\min ^{-1}$.

To determine the optimum temperature for glutamate synthase activity, duplicate tubes, each containing $2 \mathrm{ml}$ of complete reaction mixture, were incubated at the desired temperature for $5 \mathrm{~min}$. The reaction was stopped by the addition of $0.1 \mathrm{ml} 5 \mathrm{M}-\mathrm{NaOH}$; the absorbance at $340 \mathrm{~nm}$ was recorded immediately and the two values were averaged. A third reaction mixture served as a control to monitor changes at $340 \mathrm{~nm}$ in the absence of glutamine.

Light-driven glutamate synthesis was demonstrated in extracts prepared anaerobically as previously described for nitrogenase except that dithionite was omitted (Yoch, 1979). The extract was transferred by syringe anaerobically into $5 \mathrm{ml}$ Fernbach flasks containing the other glutamate synthase substrates; these flasks had previously been fitted with serum bottle caps, evacuated and refilled with argon. The complete reaction mixture $(1.5 \mathrm{ml})$ contained $100 \mathrm{~mm}$-Tricine buffer ( $\mathrm{pH} 8.0), 20 \mathrm{~mm}$-sodium succinate, $2 \mathrm{~mm}-\mathrm{NAD}^{+}, 0.01 \mathrm{~mm}-\mathrm{NADP}^{+}$, $5 \mathrm{~mm}$-glutamine, $0.5 \mathrm{~mm}$-2-oxoglutarate and enzyme (crude extract). The light intensity was saturating. After $30 \mathrm{~min}$ incubation at $32{ }^{\circ} \mathrm{C}$, the reaction was stopped by adding one drop of concentrated $\mathrm{HCl}$. The precipitated protein was removed by centrifugation and the supernatant was neutralized with $\mathrm{NaOH}$. Samples of this solution 
were analysed for glutamate enzymically with bovine glutamate dehydrogenase (EC 1.4.1.3; Sigma). The glutamate concentration was determined from a standard curve in which the rate of NADP reduction by glutamate dehydrogenase was plotted against the concentration of glutamate required to produce the given rate. Glutamate dehydrogenase was assayed according to Adachi \& Susuki (1977), except that glutamate was provided as indicated.

Rhodospirillum rubrum glutamine synthetase was assayed by the $\gamma$-glutamyl transferase assay as described by Bender et al. (1977). A pH of 7.3, which is the isoactivity point for transferase activity of the $R$. rubrum enzyme (Yoch, unpublished data), was used in this assay.

Molecular weight determinations. The molecular weight of glutamate synthase was determined by the gel filtration technique as described by Andrews (1965). Sucrose density gradient sedimentation according to Martin \& Ames (1961) provided a second method of determining the molecular weight of glutamate synthase in a protein mixture. Sucrose gradients ( 5 to $30 \%, w / v)$ were prepared in buffer A and placed on top of $4 \mathrm{ml}$ of $60 \%$ (w/v) sucrose in cellulose nitrate tubes for the Beckman SW-27 rotor. A sample $(0.5 \mathrm{ml})$ of the 35 to $45 \%\left(\mathrm{NH}_{4}\right)_{2} \mathrm{SO}_{4}$ fraction was desalted and layered on to one gradient, and standard proteins (dissolved in $0.5 \mathrm{ml}$ buffer A) were layered on to duplicate gradients. After centrifugation, $0.5 \mathrm{ml}$ fractions from the sucrose gradient were collected and assayed for both glutamate synthase and glutamine synthetase; the standard proteins were located by their absorbance at $280 \mathrm{~nm}$. The concentration of sucrose in each fraction was determined with a Bausch and Lomb refractometer.

Other assays. Protein was determined by the biuret procedure (Gornall et al., 1949) with crystalline bovine serum albumin as the reference protein. Iron was analysed with a Perkin-Elmer (model 503) atomic absorption spectrometer. Optical spectra of glutamate synthase were recorded with a Beckman model DU-8 spectrophotometer. Chromatophore membranes in column fractions were located by their red colour and quantified by the absorbance at $880 \mathrm{~nm}$ of the bound bacteriochlorophyll.

\section{RES ULTS}

\section{Activity and intracellular location of glutamate synthase}

Glutamate synthase in $R$. rubrum appeared to be partially associated with the chromatophore membranes in some preparations, whilst in others the enzyme was almost completely soluble. The amount of soluble enzyme varied between 10 and $90 \%$ from one preparation to another. Nitrogenase, in contrast, was consistently (>95\%) found in the supernatant extract. Washing the chromatophores with buffer resulted in the solubilization of 50 to $70 \%$ of the membrane-associated glutamate synthase. To determine the nature of this glutamate synthase-chromatophore association, chromatophores were chromatographed on a gel column (Bio-Gel A-5m) which could resolve membrane vesicles from high molecular weight proteins. Figure 1 shows that glutamate synthase was clearly separated from the bacteriochlorophyll-containing membranes which eluted with the front, indicating that the enzyme was only loosely associated with the membranes and that this association was easily disrupted by gel filtration chromatography. Glutamate synthase is shown here in relation to glutamine synthetase which has a similar association with these membranes.

The association of glutamine synthetase and glutamate synthase with the photosynthetic membranes of $R$. rubrum suggested that this arrangement might be necessitated by the energy requirement (ATP and NADPH, respectively) of these two enzymes. That light energy can drive at least one of these enzymes, glutamate synthase, was demonstrated by supplementing the crude extract with succinate (an electron donor) and $\mathrm{NAD}^{+}$in addition to the substrates of this enzyme and illuminating the mixture. Hydrogen and electrons from photoreduced $\mathrm{NAD}^{+}$were transferred to $\mathrm{NADP}^{+}$by the endogenous membrane-bound transhydrogenase previously described by Keister \& Yike (1967). The amount of glutamate formed was determined enzymically with glutamate dehydrogenase. Rates of glutamate photosynthesis were comparable, or even higher $\left[75 \mathrm{nmol}\right.$ glutamate formed $\min ^{-1}$ (mg protein) $\left.{ }^{-1}\right]$ than those observed in freshly prepared extracts supplemented with NADPH. This experiment demonstrates that the energy for glutamate formation can be derived from the light reaction in $R$. rubrum. 


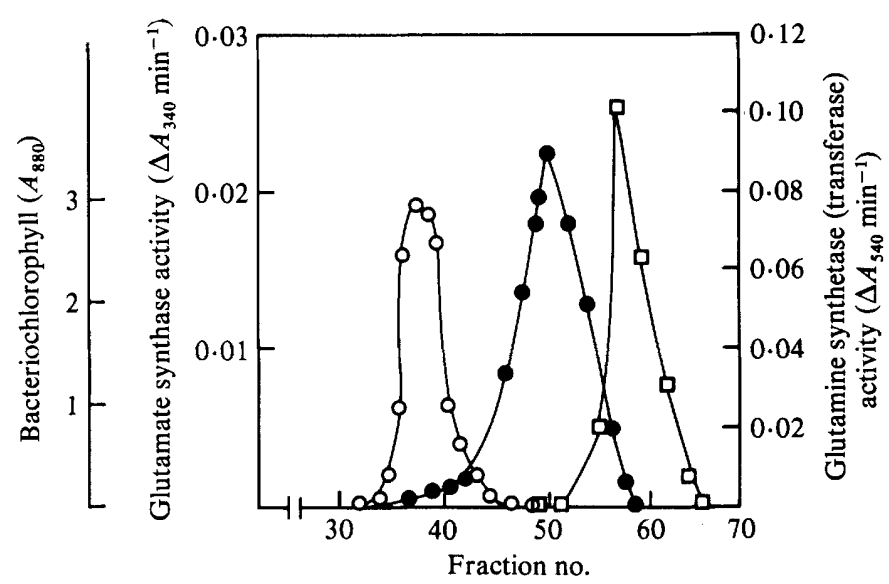

Fig. 1. Gel filtration chromatography of $R$. rubrum chromatophores. Unwashed chromatophores $(0.5 \mathrm{ml})$ were placed on a Bio-Gel A-5m column $(1.5 \times 37 \mathrm{~cm})$ equilibrated and eluted with $50 \mathrm{~mm}$-Tricine buffer ( $\mathrm{pH} 7.5$ ). Enzyme activities were determined by assaying $0.1 \mathrm{ml}$ of each fraction for glutamine synthetase and glutamate synthase. Bacteriochlorophyll (O); glutamine synthetase (O); glutamate synthase ( $\square$ ).

\section{Enzyme characteristics}

Absorption spectrum and iron content. To determine whether glutamate synthase from $R$. rubrum was an iron-containing flavoprotein similar to that isolated from other prokaryotes, it was purified approximately 200 -fold; the final specific activity was 1100 . The yield was only about $5 \%$ and attempts at further purification were unsuccessful. Although glutamate synthase was stable for at least 6 weeks at $-10^{\circ} \mathrm{C}, 2$-oxoglutarate and 2-mercaptoethanol did not stabilize the $R$. rubrum enzyme during purification. These compounds stabilize the $E$. coli and $K$. aerogenes enzymes (Miller \& Stadtman, 1972; Trotta et al., 1974).

Preliminary evidence for the presence of iron in $R$. rubrum glutamate synthase is seen in Fig. 2. After fractionation with $\left(\mathrm{NH}_{4}\right)_{2} \mathrm{SO}_{4}$ and two DE-52 cellulose chromatography steps, iron co-chromatographed with glutamate synthase activity on a gel filtration column. The enzyme was faintly yellow until this final gel filtration step in which it became very dilute. The absorption spectrum of the peak fractions from the final column showed absorption maxima at 373,450 and a shoulder at $475 \mathrm{~nm}$, indicating that glutamate synthase also co-chromatographed with flavin. The co-migration of iron and flavin with enzyme activity is presented as preliminary evidence that $R$. rubrum glutamate synthase is an iron (probably iron-sulphur) flavoprotein.

$p H$ and temperature optima. A pH optimum of 8 was found for $R$. rubrum glutamate synthase activity; crude extracts showed a somewhat broader $\mathrm{pH}$ profile. The temperature optimum for enzyme turnover was approximately $43^{\circ} \mathrm{C}$.

Substrate requirements and kinetic parameters. The $R$. rubrum glutamate synthase was strictly dependent on NADPH for activity; no activity was found with NADH even at concentrations 10 - to 100 -fold higher than the NADPH concentrations used. All substrate utilization followed typical Michaelis-Menten kinetics. The direct plot of enzyme activity versus substrate concentration resulted in hyperbolic curves with all three substrates glutamine, NADPH and 2-oxoglutarate. The apparent $K_{\mathrm{m}}$ values for glutamine, NADPH and 2-oxoglutarate were $130 \mu \mathrm{M}, 15 \mu \mathrm{M}$ and $35 \mu \mathrm{M}$, respectively. Because $\mathrm{NaCl}$ was shown to influence the molecular weight of glutamate synthase (see below), the $K_{\mathrm{m}}$ values for both glutamine and 2-oxoglutarate were determined with enzyme prepared both in the absence and 


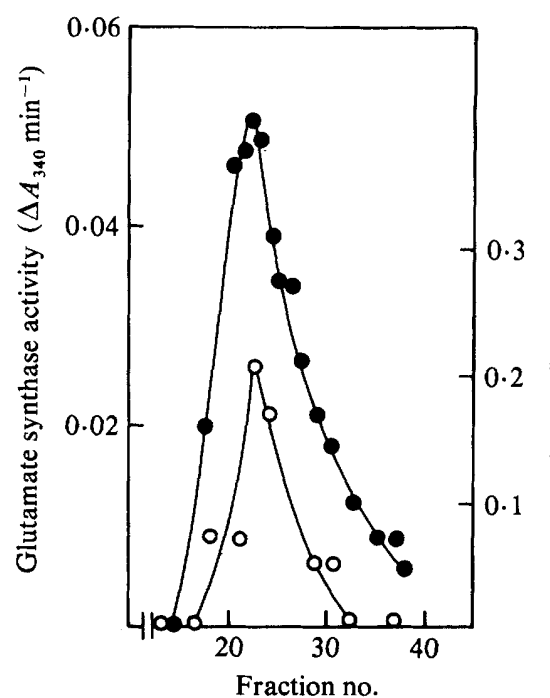

Fig. 2

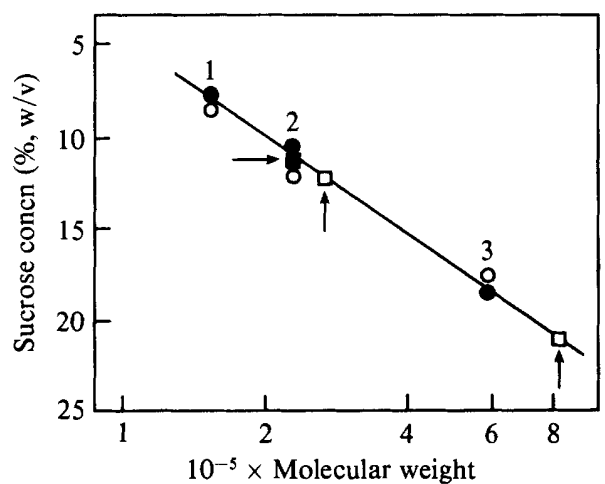

Fig. 3

Fig. 2. Co-chromatography of iron $(O)$ with glutamate synthase activity (O). The column $(1.0 \times$ $37 \mathrm{~cm}$ ) was Bio-Gel A-1.5 m equilibrated and eluted with $50 \mathrm{~mm}$-Tricine containing $0.4 \mathrm{M}-\mathrm{NaCl}$.

Fig. 3. Determination of the molecular weight of glutamate synthase by sucrose density centrifugation. Protein standards [1, aldolase (mol. wt 158000); 2, catalase (232000); 3, R. rubrum glutamine synthetase (600000)] were centrifuged in sucrose gradients containing either $0.4 \mathrm{M}-\mathrm{NaCl}(\mathrm{O})$ or Tricine buffer (O); $R$. rubrum glutamate synthase (arrowed) was centrifuged on sucrose gradients in the presence $(\square)$ or absence $(\square)$ of $0.4 \mathrm{M}-\mathrm{NaCl}$.

presence of $0.4 \mathrm{M}-\mathrm{NaCl}$. Both forms of the enzyme showed identical affinity $\left(K_{\mathrm{m}}\right)$ for the substrates glutamine and 2-oxoglutarate. Only the high molecular weight form of glutamate synthase was used to determine the NADPH saturation characteristics.

Molecular weight. The elution of glutamate synthase from gel filtration columns later than glutamine synthetase (Fig. 1) indicates that its molecular weight is below 600000 (Carithers et al., 1979). However, molecular weight determinations on a standardized Bio-Gel column in the presence of $0.4 \mathrm{M}-\mathrm{NaCl}$ indicated a molecular weight for this enzyme of about 820000 . Attempts to confirm this result using the sucrose gradient technique of Martin \& Ames (1961) again indicated an enzyme with a lower molecular weight; the values obtained were $260000 \pm 40000$ (Fig. 3, 口). It was soon apparent that $\mathrm{NaCl}$ was affecting the molecular weight of glutamate synthase. When $0.4 \mathrm{M}-\mathrm{NaCl}$ was incorporated into the sucrose gradients, enzyme activity was found in two bands, one with an apparent molecular weight of 260000 and the other 840000 (Fig. 3, $\square$ ). The latter value is in good agreement with the value obtained by gel filtration with buffers containing $\mathrm{NaCl}$.

This increase in apparent molecular weight in the presence of $\mathrm{NaCl}$ also occurred with the glutamate synthase from Klebsiella pneumoniae (Fig. 4). Increased exposure of this enzyme to $\mathrm{NaCl}$ increased its apparent molecular weight. Under three different conditions, ranging from no exposure to $\mathrm{NaCl}$ to preincubation of the enzyme overnight with $\mathrm{NaCl}$ prior to chromatography, the ratio $V_{\mathrm{e}}$ to $V_{0}$ decreased from 1.6 to 1.3 indicating that the molecular weight of $K$. pneumoniae glutamate synthase was increasing. From these observations it is apparent that not only does $R$. rubrum glutamate synthase aggregate in the presence of $\mathrm{NaCl}$, but so also does that of at least one other organism. As discussed below, this phenomenon may account for the two molecular weight classes of glutamate synthase reported in the literature. 


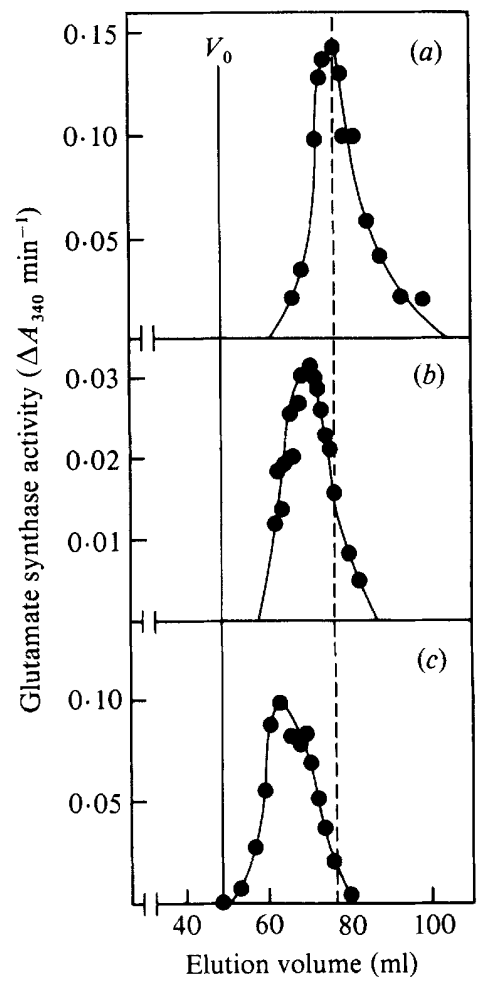

Fig. 4. Effect of $\mathrm{NaCl}$ on the elution volume of Klebsiella pneumoniae glutamate synthase from gel filtration columns. (a) Activity profile of a 35 to $45 \%$ saturated $\left(\mathrm{NH}_{4}\right)_{2} \mathrm{SO}_{4}$ precipitate run on a Sephacryl S300 column $(1.5 \times 90 \mathrm{~cm})$ equilibrated and eluted with $50 \mathrm{mM}$-Tricine $(\mathrm{pH} 8.0)$ containing 2 mM-2-oxoglutarate. (b) As (a) except that the column buffer included $0.4 \mathrm{M}-\mathrm{NaCl}$. (c) Enzyme preparation was incubated for $24 \mathrm{~h}$ at $4{ }^{\circ} \mathrm{C}$ in the presence of $0.4 \mathrm{M}-\mathrm{NaCl}$ before chromatography in the presence of $0.4 \mathrm{M}-\mathrm{NaCl}$.

\section{DISCUSSION}

Glutamate synthase was detected in the photosynthetic bacterium $R$. rubrum under all conditions of growth (high and low $\mathrm{NH}_{4}{ }^{+}$concentration, nitrogen starvation and $\mathrm{N}_{2}$ fixation) in keeping with the earlier observations of Weare \& Shanmugam (1976). The glutamate synthase activity after growth with excess $\mathrm{NH}_{4}^{+}$was about half that found in nitrogen-starved cells (Yelton, 1980). The presence of this enzyme in bacteria grown with excess ammonia, where it has no obvious role in ammonia assimilation, raises interesting questions about its physiological function in these cells. The physical and enzymic nature of glutamate synthase in the purple nonsulphur bacteria is of considerable interest, because of increasing evidence (cited below) suggesting a role for this enzyme in the regulation of nitrogenase. Preliminary evidence suggests that glutamate synthase from $R$. rubrum contains iron (Fig. 2) and flavin and thus may be an iron-sulphur flavoprotein similar to the enzymes isolated from other bacteria (Miller \& Stadtman, 1972; Trotta et al., 1974; Adachi \& Susuki, 1977; Hemmilä \& Mäntsälä, 1978). Definitive evidence on this point must, however, await its purification to homogeneity which will first require a method for stabilizing its activity.

The affinity of $R$. rubrum glutamate synthase for its substrates is in the same range as those from other organisms (see Table 1). The low $K_{\mathrm{m}}$ for glutamine $(130 \mu \mathrm{M})$ is evidence for a physiological role for glutamate synthase in which the enzyme scavenges for glutamine under nitrogen-fixing or nitrogen-starvation conditions. This binding constant has regulatory implications because free glutamine has been shown in R. rubrum (Neilson \& Nordlund, 
Table 1. Summary of characteristics of bacterial glutamate synthases

\begin{tabular}{|c|c|c|c|c|c|}
\hline \multirow[b]{2}{*}{ Species } & \multicolumn{3}{|c|}{$K_{\mathrm{m}}(\mu \mathrm{M})$} & \multirow[b]{2}{*}{$\begin{array}{l}\text { Molecular } \\
\text { weight** }\end{array}$} & \multirow[b]{2}{*}{ Reference } \\
\hline & NADPH & Glutamine & $\begin{array}{l}\text { 2-Oxo- } \\
\text { glutarate }\end{array}$ & & \\
\hline Rhodospirillum rubrum & 15 & 130 & 35 & $\begin{array}{l}263000^{1} \\
840000^{2}\end{array}$ & This study \\
\hline Escherichia coli & $7 \cdot 7$ & 250 & $7 \cdot 3$ & $800000^{2}$ & Miller \& Stadtman (1972) \\
\hline Klebsiella aerogenes & 12 & 300 & 300 & $227000^{1}$ & Trotta et al. (1974) \\
\hline Thiobacillus thioparus & $3 \cdot 0$ & 1100 & 50 & $280000^{1}$ & Adachi \& Susuki (1977) \\
\hline Bacillus megaterium & $7 \cdot 1$ & 200 & 9 & $840000^{2}$ & Hemmilä \& Mäntsälä (1978) \\
\hline
\end{tabular}

1975 ) and Rhodopseudomonas sphaeroides (Jones \& Monty, 1979) to be an inhibitor of nitrogenase activity. The mechanism of this inhibitory process is not yet understood, but it seems to be related to the nitrogenase activation system discovered by Ludden \& Burris (1976) because the in vivo inactivation of nitrogenase by glutamine (Carithers et al., 1979) can be reactivated in vitro by this $\mathrm{Mn}^{2+}$-dependent activation system. Consistent with this view is evidence showing that a mutation blocking glutamine biosynthesis in $R$. capsulata resulted in an altered regulatory response to its nitrogen substrates (Yoch, 1980).

An interesting aspect of this study was the finding that the molecular weight of glutamate synthase was greatly influenced by the presence or absence of $\mathrm{NaCl}$ (Fig. 3). In the absence of $\mathrm{NaCl}$ the enzyme had a molecular weight in the 200000 to 300000 range, while in the presence of $\mathrm{NaCl}$ it increased to over 800000 . This phenomenon may result from salt increasing the hydrophobic interaction between the low molecular weight molecules causing aggregation. $\mathrm{NaCl}$ had a similar effect on $K$. pneumoniae glutamate synthase in that it increased the $V_{\mathrm{e}}$ to $V_{0}$ ratio (Fig. 4) (i.e., the apparent molecular weight) which indicates that the salt effect is not peculiar to the $R$. rubrum enzyme. That this molecular weight variation may be a property of all glutamate synthases was suggested by the fact that enzymes prepared in the absence of salts $(\mathrm{NaCl}$ or $\mathrm{KCl})$ such as those from $K$. aerogenes (Trotta et al., 1974) and T. thioparus (Adachi \& Susuki, 1977) were reported to have a low molecular weight, while those from $E$. coli (Miller \& Stadtman, 1972) and B. megaterium (Hemmilä \& Mäntsälä, 1978) prepared and analysed in the presence of salt showed a high molecular weight (Table 1). A second slow moving form of $E$. coli glutamate synthase was also observed, on sucrose density gradients containing 0.1 M-KCl (Miller \& Stadtman, 1972). This and similar observations with crude extracts led these workers to postulate that the purified high molecular weight enzyme might be composed of four catalytically active dimers. Our data are consistent with this view.

In summary, glutamate synthase from $R$. rubrum closely resembles those enzymes found in other bacteria. The effect of glutamine on regulating nitrogenase activity in photosynthetic bacteria suggests that glutamate synthase may be involved in this process. If so, this enzyme will receive considerable attention in future studies on nitrogenase regulation.

We wish to thank Ms Mona Cantu for her excellent technical assistance. This work was supported by a Public Health Service grant AI-16040-01 from the National Institute of Allergy and Infectious Diseases and from HEW Biomedical Research grant (no. 5S07 RR07160).

\section{REFERENCES}

ADACHI, K. \& Susuki, I. (1977). Purification and properties of glutamate synthase from Thiobacillus thioparus. Journal of Bacteriology 129, 1173-1182.
ANDREws, P. (1965). The gel-filtration behaviour of proteins related to their molecular weights over a wide range. Biochemical Journal 96, 595-606. 
Bender, R. A., Janssen, K. A., Resnick, A. D., Blumenberg, M., Foor, F. \& Magasanik, B. (1977). Biochemical parameters of glutamine synthetase from Klebsiella aerogenes. Journal of Bacteriology 129, 1001-1009.

Brown, C. M. \& Herbert, R. A. (1977a). Ammonia assimilation in purple and green sulphur bacteria. FEMS Microbiology Letters 1, 39-42.

Brown, C. M. \& Herbert, R. A. (1977b). Ammonia assimilation in members of the Rhodospirillaceae. FEMS Microbiology Letters 1, 43-46.

Carithers, R. P., Yoch, D. C. \& Arnon, D. I. (1979). Two forms of nitrogenase from the photosynthetic bacterium Rhodospirillum rubrum. Journal of Bacteriology 137, 779-789.

Gornall, A. G., Bardawill, C. J. \& David, M. M. (1949). Determination of serum proteins by means of the biuret reaction. Journal of Biological Chemistry 177, 751-760.

Hemmilä, I. A. \& MÄNTSÄLÄ, P. I. (1978). Purification and properties of glutamate synthase and glutamate dehydrogenase from Bacillus megaterium. Biochemical Journal 173, 45-52.

Herbert, R. A., Siefert, E. \& Pfenning, N. (1978). Nitrogen assimilation in Rhodopseudomonas acidophila. Archives of Microbiology 119, 1-5.

Johansson, B. C. \& GEST, H. (1976). Inorganic nitrogen assimilation by the photosynthetic bacterium Rhodopseudomonas capsulata. Journal of Bacteriology 128, 683-688.

Johansson, B. C. \& Gest, H. (1977). Adenylylation/ deadenylylation control of the glutamine synthetase of Rhodopseudomonas capsulata. European Journal of Biochemistry 81, 365-371.

Jones, B. L. \& Monty, K. J. (1979). Glutamine as a feedback inhibitor of the Rhodopseudomonas sphaeroides nitrogenase system. Journal of Bacteriology 139, 1007-1013.

KeISTER, D. L. \& YIKE, N. J. (1967). Energy-linked reactions in photosynthetic bacteria. II. The energydependent reduction of oxidized nicotinamideadenine dinucleotide phosphate by reduced nicotinamide-adenine dinucleotide in chromatophores of Rhodospirillum rubrum. Biochemistry 6 , 3847-3857.

LudDen, P. W. \& Burris, R. H. (1976). Activating factor for the iron protein of nitrogenase from Rhodospirillum rubrum. Science 194, 424-427.

Martin, R. G. \& Ames, B. N. (1961). A method of determining the sedimentation behavior of enzymes: application to protein mixtures. Journal of Biological Chemistry 236, 1372-1379.
Miller, R. E. \& Stadtman, E. R. (1972). Glutamate synthase from Escherichia coli. Iron-sulfide flavoprotein. Journal of Biological Chemistry 247, 7407-7419.

Nagatani, H., Shimizu, M. \& Valentine, R. C. (1971). The mechanism of ammonia assimilation in nitrogen fixing bacteria. Archiv für Mikrobiologie 79, 164-175.

Neilson, A. H. \& Nordlund, S. (1975). Regulation of nitrogenase synthesis in intact cells of Rhodospirillum rubrum: inactivation of nitrogen fixation by ammonia, L-glutamine and L-asparagine. Journal of General Microbiology 91, 53-62.

Ormerod, J. G., Ormerod, K. S. \& Gest, H. (1961). Light-dependent utilization of organic compounds and photoproduction of molecular hydrogen by photosynthetic bacteria; relationships with nitrogen metabolism. Archives of Biochemistry and Biophysics 94, 449-463.

Trotta, P. P., Platzer, K. E. B., Haschemeyer, R. H. \& Meister, A. (1974). Glutamine-binding subunit of glutamate synthase and partial reactions catalysed by this glutamine amidotransferase. Proceedings of the National Academy of Sciences of the United States of America 71, 4607-4611.

WALL, J. D. \& GEST, H. (1979). Derepression of nitrogenase activity in glutamine auxotrophs of Rhodopseudomonas capsulata. Journal of Bacteriology 137, 1459-1463.

WEARE, N. M. (1978). The photoproduction of $\mathrm{H}_{2}$ and $\mathrm{NH}_{4}{ }^{+}$fixed from $\mathrm{N}_{2}$ by a derepressed mutant of Rhodospirillum rubrum. Biochimica et biophysica acta 502, 486-494.

Weare, N. M. \& Shanmugam, K. T. (1976). Photoproduction of ammonium from $\mathrm{N}_{2}$ in Rhodospirillum rubrum. Archives of Microbiology 110, 207-213.

Yelton, M. M. (1980). M.S. thesis, University of South Carolina, Columbia, U.S.A.

Yoch, D. C. (1979). Manganese, an essential trace element for $\mathrm{N}_{2}$ fixation by Rhodospirillum rubrum and Rhodopseudomonas capsulata: role in nitrogenase regulation. Journal of Bacteriology 140, 987-995.

Yoch, D. C. (1980). Regulation of nitrogenase A and $\mathrm{R}$ concentrations in Rhodopseudomonas capsulata by glutamine synthetase. Biochemical Journal 187, 273-276.

Yoch, D. C. \& Pengra, R. M. (1966). Effect of amino acids on the nitrogenase system of Klebsiella pneumoniae. Journal of Bacteriology 92, 618622. 